\title{
Statutes of the International Society of Geographical Pathology
}

The object of the International Society of Geographical Pathology is to study the relations which may exist between diseases and the geographical environments in which they occur.

The Office of the Society is in Switzerland.

Members:

The Society consists of medical and non-medical persons, interested in the problems of geographical pathology. They are members of the Society. The enrolment as a member is made by the Secretary General of the Society.

The members of the Society meet every third year in a conference (see $\S 7$ ); they present communications and participate in the scientific and administrative discussions. They have the right to vote in the course of the administrative meeting of the Society.

Every member pays a yearly contribution of Swiss francs 5.-, which will be transmitted to the Secretary General by each member or by the National Committees before April 1st each year. This contribution serves principally to cover the costs of administration and correspondence.

638 Statutes of the International Society of Geographical Pathology

4. National and Regional Committees:

Each country forms its own National or Regional Committee consisting of medical and non-medical persons. The constitution of the National Committees may vary in accordance with the subject chosen for the conference. These committees are responsible for collecting information and the results of scientific investigation. They are recognized by the Society and thus represent scientific commissions of the Society. Each committee elects a President and a Secretary. The duties of the Secretary are:

to maintain close contact with the Secretary General;

to keep a list of his country's members, collect their annual subscriptions and remit them to the account of the Society; and

in particular to collate the results of enquiries sponsored by his National Committee and draft these as a national report (or reports) (§ 7).

5. The Society is governed by an Executive Committee. This Committee

consists of the Secretary General and the Presidents of the two preceding con

ferences. Furthermore there are 6 regular members and 4 assessors who are

elected at the administrative meeting by the majority of the members present.

They hold office for 3 years, that is until the next conference, and can be re-

elected.

On election the Executive Committee will appoint the President and two Vice-Presidents for the ensuing 3 years. The President of the Executive Committee is also the President of the Society and ipso facto the designated President of the next conference. Together with the Secretary General he represents the Society externally. He is the organiser of the conference which he will direct together with the Secretary General. At the end of the conference his office as President is terminated.

The office of Secretary General is a permanent institution, maintaining the relationship between the Executive Committee and the National Committees. The Secretary General manages the affairs of the Society in close cooperation with the Executive Committee and especially with its President. He deals with the normal correspondence and is responsible for maintaining relations with the international organisations to which the Society belongs. He is expected to collect all scientific data from the different countries which participate in the enquiries organised by the Society. He organises the scientific part of the conference in co-operation with the Presidents of the conferences. Together with the Secretary of the conferences he publishes the Transactions. The Secretary General is also the Treasurer of the Society.

As a rule, the Society organises a conference every third year. The subject for discussion is-if possible-chosen three years in advance by the general assembly of members.

The Executive Committee, together with the National Committees appoint the main rapporteurs. The result of the enquiries organised by the National Committees will be summarized in one (or several) national reports. These must be sent in good time to the Secretary General by the Secretaries of the National Committees. They form the basis for the main reports given at the

Statutes of the International Society of Geographical Pathology 639

conference by the main rapporteurs. The national reports remain the property of the National Committees.

The conferences are restricted to the members of the Society. Persons interested in geographical-pathological problems or in the subject for discussion and working in this field may however participate, if the National Committee of their country agrees.

Each participant pays a conference fee, which serves to cover the expenses incurred in connection with the preparation and organisation of the conference, the publication of the discussions, the management of the Office of the Secretary General and the compulsory contributions to the international organisations to which the Society belongs. The subscription will be fixed by the Secretary General and the President of the conference according to the financial circumstances at the time and the foreign money exchange situation in the countries concerned.

All financial matters of the Society are handled by the Secretary General. During the administrative meeting, which is held in the course of each conference, two members will be chosen to audit the Secretary's accounts. They report on the balance-sheet and propose the adoption of the accounts to the Society. 
10. Meeting of the members.

In the course of each conference the members meet to discuss the affairs of the Society. Certain matters to be considered are:

The appointment of the new Executive Committee; the examination of the financial situation; the discussion and choice (by vote) of the subject for the next enquiry; and the choice of the place at which the next conference will be held.

Each member has the right to make suggestions which in his opinion might be of importance for the organisation of the Society. Such suggestions should be forwarded to the Secretary General at least one month before the beginning of the conference.

The practical organisation of the conference lies in the hands of the National Committee in whose country the conference is being held, and especially of its President. The President is responsible for the technical organisation of the conference. Together with the Secretary General he will be responsible for the wording, printing and dispatching of invitations and programmes, as well as for the appearance of the advertisements of the conference in the press.

These Statutes can be altered if the National Committees have been given notice at least 3 months in advance. An alteration can only be made if the majority of the Presidents of the National Committees, or their representatives, being present at an administrative meeting, agree.

July 1957. 